\title{
BIOGAS PRODUCTION POTENTIAL FROM MUNICIPALORGANIC WASTES IN DHAKA CITY, BANGLADESH
}

\author{
Nusrat Jahan Imu ${ }^{1}$, Dido Mann Samuel ${ }^{2}$ \\ ${ }^{1}$ Research Assistant, Daffodil International University, Dhaka-1207, Bangladesh \\ ${ }^{2}$ Assistant Lecturer, Federal University, Ndufu-Alike Ikwo (FUNAI), Nigeria
}

\begin{abstract}
This study aimed at assessing the biogas production potential from municipal organic wastes and conversion of biogas to electric energy for Dhaka, Bangladesh. The generation of solid waste and demand for energy is increasing simultaneously in Dhaka city due to the rapid growth of population and industrialization. As a source of renewable energy using of municipal organic waste should be encouraged to save the environment from harmful GHG as well as to minimize the energy deficiency. Among the various biogas production technologies, anaerobic digestion is one of the promising and environmental friendly technology for treating organic waste. In Dhaka city, there are huge potential to produce biogas from municipal waste because the volume of solid waste of this city is 4000-5000 ton/day with composition of 3/4 percentage organic waste. Bio-waste (food waste) was used as feedstock for anaerobic digestion process. Two inoculums-sewage sludge and digested maize silage were used with organic waste. About $0.57 \mathrm{~m}^{3} / \mathrm{kg}_{\text {ODM }}$ of biogas and $0.22 \mathrm{~m}^{3} / \mathrm{kg}_{O D M}$ methane was produce from the anaerobic digestion (AD) of a mixture of bio waste and digested maize silage. Consequently, $0.094 \mathrm{~m}^{3} / \mathrm{kg}_{\text {ODM }}$ of biogas and $0.043 \mathrm{~m}^{3} / \mathrm{kg}_{\text {ODM }}$ methane was generated from the fermentation of bio waste with sewage sludge. Biogas-to-electricity potential was found to be $83.66 \mathrm{MW}$ based on the lower value of $0.094 \mathrm{~m}^{3} / \mathrm{kg}_{\text {ODM }}$ volume biogas produced, which accounts for about $3.8 \%$ of the present demand of Dhaka city.
\end{abstract}

Key Words: Municipal organic waste, anaerobic digestion, biogas, energy generation, electricity $* * *$

\section{INTRODUCTION}

Dhaka, the capital city of Bangladesh, is one of the 10 biggest Megacities in the world with a population of 14.5 million in 2011 [1].Waste generation is observed to increase considerably due to rapid population growth in Dhaka city. The daily estimated waste generation of Dhaka cityis 4000-5000 ton [2, 3] of which the organic portion is about $3 / 4$ percent [4]. However, from the survey report of Japan International Cooperation Agency (JICA), the daily average collection of waste is only 2244 ton [5]. The rest of uncollected wastes are being dumped on open spaces or besides the street. The organic fraction of municipal solid waste is digested through anaerobic digestion, which results in the release harmful Greenhouse gas (GHG) methane [6] in the environment.Several waste-to-energy generation technologies such as incineration, landfill, and anaerobic digestion do exist. Nonetheless, anaerobic digestion technology is the most promising environment friendly for treating solid waste among these technologies [7]. In Dhaka, an incineration plant is being planned with the ultimate goal ofminimize the municipal waste volume and to meet the growing demand for energy[8].

According to Singhal, Y. et al., 2012[9], municipal organic waste in developing countries is carbohydrate rich waste, which has been intensively used for biogas production.Due to the composition of municipal solid waste, the energy conversion technology must be selected very carefully. The composition of organic waste from municipal solid waste depends on number of factors including geographical location, culture, food habits, seasons and living standard [10]. If the waste contains high amount of moisture, burning process will not be much efficient for energy generation. Alam et al [11] reported that the moisture content of solid waste in Dhaka varies from 50-60\% and contains high amount of carbohydrate. This implies that biogas production from solid organic waste through anaerobic digestion would be a promising green energy source for Dhaka.This study aims to provide the information about the biogas production potential from the anaerobic digestion (AD) of organic waste in Dhaka in addition to providing information on the electricity generation potential from biogas.

\section{LITERATURE REVIEW}

Alastair J. Ward et al. [12] found that the methane yield from the co-digestion of municipal organic waste and digested sludge is $0.29 \mathrm{~m}^{3} / \mathrm{kg}$ as the methane yield value depends not onlyon the sorting method, but also on the location from which thematerial was sourced and the time of year of collection.Xiguang Chen et al. [13] stated that co-digestion of municipal organic waste and sewage sludge or digested sludge can enhance the methane production. Wakadikar et al. [14] stated that cumulative methane $\left(\mathrm{CH}_{4}\right)$ production from cellulose, food and vegetable wastes and municipal solid wastes varied from 0.23-1.51, 0.25-0.92, $0.14-0.55$ and $0.07-0.21 \mathrm{~L} / \mathrm{kg}$ volatile solids.According to $\mathrm{T}$. Bond et al. [15] biogas production from sewage sludge varies from $0.35-0.5 \mathrm{~m}^{3} / \mathrm{Kg}_{\mathrm{ODM}}$. But Co-digestion of 
sewage sludge's with MSW can improve the biogas production varies between 0.4 and $0.6 \mathrm{~m}^{3} / \mathrm{Kg}_{\mathrm{ODM}}$ stated by A.J. Ward et al.[16] and P. Sosnowski et al [17].Davidsson et al. [18] stated that biogas production from organic fraction of municipal solid waste varies from the range of 0.4 to $0.6 \mathrm{~m}^{3} / \mathrm{kg}_{\text {ODM }}$.

\section{MATERIALS AND METHOD}

\section{Materials}

To assessing the biogas production potential of municipal organic wastes, laboratory test was conducted at the University of Applied Science, Cologne, Germany. Food wastes collected from households with similar food habit in Cologne were used as input material for the fermentation process. Approximately three-kilogram organicfood waste mainly the bio waste was collected for a period of one week for the experiment. All collected waste was analyzed for dry matter (DM) and organic dry matter (ODM). Prior to batch fermentation, the components of bio waste were crushed using an electrical blender. Approximately $150 \mathrm{ml}$ of water was added during blending to produce a homogenous paste of the test sample. This is very important since bio waste characterizes by an inhomogeneous material composition [19]. The blended mixture was afterwards stored in the refrigerator at temperature $-4^{\circ} \mathrm{C}$. The quantity of test sample added to measured volume of inoculum used for each batch fermentation process was computed using formula (1) below according to VDI 4630 [20] so as to prevent the inhibition of biogas production due to add too much or less substrate in the inoculum.

$O D M_{\text {substrate }} / O D M_{\text {seedingsludge }} \triangleleft 0.5$ (1)

Calculated bio waste quantity for the $1^{\text {st }}, 2^{\text {nd }}$ and $3^{\text {rd }}$ fermentation process were $7 \mathrm{~g}, 300 \mathrm{~g}$ and $100 \mathrm{~g}$ respectively and the computed volumes inoculum were 225 $\mathrm{g}, 2700 \mathrm{~g}$ and $2700 \mathrm{~g}$ respectively. There were in total five reactors in which three reactors were filled with the mixture of inoculum and bio waste while the other two reactors were filled with the inoculum only.

Two inoculums namely, sewage sludge and digested maize silage were used for the batch fermentation process. Sewage sludge was collected from a local wastewater treatment plant located in Aggerverband, North RheinWestphalia while the digested maize silagewas collected from a biogas plant located in Porz, Cologne. Both inoculums were assessed to determine the presence of microorganisms needed for the AD process. The inoculums were transported to the Biogas laboratory and stored in an oven for seven days at $38^{\circ} \mathrm{C}$ [20]to allow the microorganisms present some time to decompose the organic materials presents in the inoculum. The laboratory study consisted of three batch tests procedures for assessing the biogas production potential. Each batch anaerobic digestion tests was performed under mesophilic condition at $38^{\circ} \mathrm{C}$.
Table- 1 shows the brief information about the experimental arrangement. To facilitate the evaluation of biogas and methane yield from bio wastes the first experiment was performed using a $0.5 \mathrm{~L}$ reactor while the second and third tests were performed using $3 \mathrm{~L}$ reactors. Because it is necessary to determine the right quantity of substrate that inhibition of biogas production can occur due to excess or less feeding in to the reactor. The $1^{\text {st }}, 2^{\text {nd }}$ and $3^{\text {rd }}$ fermentation tests were operated for 13 days, 16 days and 15 days respectively.

Table 1: Experiments arrangement.

\begin{tabular}{|c|c|c|}
\hline Batch 1 & Batch 2 & Batch 3 \\
\hline $\begin{array}{l}\text { Bio waste }+ \\
\text { sewage sludge } \\
\text { (with } 0.5 \mathrm{~L} \\
\text { reactor) }\end{array}$ & $\begin{array}{l}\text { Bio waste }+ \\
\text { digested maize } \\
\text { silage(with } 3.0 \mathrm{~L} \\
\text { reactor) }\end{array}$ & $\begin{array}{l}\text { Bio waste + sewage } \\
\text { sludge (with } 3.0 \mathrm{~L} \\
\text { reactor) }\end{array}$ \\
\hline $\begin{array}{l}\text { Amount of bio } \\
\text { waste }=7.0 \mathrm{~g}, \\
7.43 \mathrm{~g} \text { and } 7.6 \mathrm{~g}\end{array}$ & $\begin{array}{l}\text { Amount of bio } \\
\text { waste }=297 \mathrm{~g}, \\
300 \mathrm{~g} \text { and } 300.50 \mathrm{~g}\end{array}$ & $\begin{array}{l}\text { Amount of bio waste } \\
=101.7 \mathrm{~g}, 101.5 \mathrm{~g} \text { and } \\
101.6 \mathrm{~g}\end{array}$ \\
\hline $\begin{array}{l}\text { Amount of } \\
\text { sewage sludge }= \\
225.29,225.21 \\
\text { and } 225.29\end{array}$ & $\begin{array}{l}\text { Amount of } \\
\text { digested maize } \\
\text { silage }=2647 \mathrm{~g}, \\
2736.7 \mathrm{~g} \text { and } 2647 \mathrm{~g}\end{array}$ & $\begin{array}{l}\text { Amount of sewage } \\
\text { sludge }=2700 \mathrm{~g}, \\
2703 \mathrm{~g} \text { and } 2703 \mathrm{~g}\end{array}$ \\
\hline $\begin{array}{l}\text { Operating } \\
\text { duration = } 13 \\
\text { days }\end{array}$ & $\begin{array}{l}\text { Operating duration } \\
=16 \text { days }\end{array}$ & $\begin{array}{l}\text { Operating duration = } \\
15 \text { days }\end{array}$ \\
\hline
\end{tabular}

\section{Analytical Methods}

According to VDI 4630 (2006) [20], Batch type fermentation process is a process where biodegradable materials are fed once into a bioreactor under anaerobic condition. This allows for evaluating fermentation ability and biogas yield of fed-in substrate. From the batch test conducted the author obtained information regarding:

- The potential biogas yield from the mixture of materials used

- Quantitative assessment of the speed of anaerobic degradation of material

Dry matter (DM\%), organic dry matter (ODM) and $\mathrm{pH}$ were determined as suggested by the VDI 4630 (2006) while FOS/TAC was determined according to Lossie and Pütz, 2008 [21]. The volume and composition of biogas produced were measured and recorded on a daily basis.

Applying the procedure suggested by VDI 4630 [20], $30 \mathrm{~g}$ of sample was placed in a crucible for dry matter measuring. This was done in triplicate. Then three crucibles were placed inside an oven for 24 hours at $105^{\circ} \mathrm{C}$.Dried samples contained in crucibles were placed in a glass bowl (Exsikkator) for 30 minutes before the weight loss from each crucible was measured.

The empirical formula for measuring DM content is given by:

$\operatorname{DM}(\%)=\left[\left(m_{c}-m_{a}\right) /\left(m_{b}-m_{a}\right)\right] * f$ 
Where, DM - Total solids

$\mathrm{m}_{\mathrm{a}}-$ mass of empty crucible

$\mathrm{m}_{\mathrm{b}}-$ mass of crucible and fresh sample

$\mathrm{m}_{\mathrm{c}}-$ mass of crucible and dry sample

$\mathrm{f}-$ conversion factor, $\mathrm{f}=100$ for $\mathrm{DM}[\%]$ and $\mathrm{f}=$ 1000 for DM $[\mathrm{g} / \mathrm{kg}]$

Measurement of the organic dry matter (ODM) was intended for thedetermination of weight loss on ignition of the DM. Organic dry matter (ODM) was measured using the first masses of the samples that were dried at $105^{\circ} \mathrm{C}$ as input materials. These were subjected to a temperature 550 ${ }^{\circ} \mathrm{C}$ until a constant a constant weight was reached. Volatile organic substances which escape during drying at $105{ }^{\circ} \mathrm{C}$ are not registered by this method and will need to be determined separately. According to VDI 4630 [20], the measurement procedure is below:

- Dry samples from DM determination were used for this purpose

- Test samples were burn in the furnace for 3-4 hours at $550^{\circ} \mathrm{C}$.

- Heat-treated specimens were placed in a glass bowl (Exsikkator) for 25-30 minutes at the room temperature prior to determination of weight loss.

The measured value of ODM was calculated by applying the following formula:

$O D M[/ \% D M]=\left[\left(m_{b}-m_{c}\right) /\left(m_{b}-m_{a}\right)\right]^{*} 100[\%]$

Where, ODM [/\%DM]- Organic dry matter based on DM $\mathrm{m}_{\mathrm{a}}$ - weight of empty crucible

$\mathrm{m}_{\mathrm{b}}-$ weight of crucible and DM

$\mathrm{m}_{\mathrm{c}}-$ weight of crucible and ash

FOS/TAC analysis was done in order to determine the quotient of the volatile acid concentration and the buffer capacity of the inoculums used. Microorganism in inoculum degrades the organic fraction of sample hence FOS/TAC value is used to monitor the fermentation process in biogas reactors. TheFOS/TAC value should not be less than 0.45 ; otherwise the bacteria would be overloaded. On the other hand when FOS/TAC value is below 0.25 , the bacteria are said to be 'hungry'. In order to monitor the fermentation process FOS/TAC value is used as guide value.

FOS/TAC $=($ Value $B * 1.66-0.15) * 500 /($ Value $A * 250)$ (4)

\section{Experiment set-up}

According to German Standard VDI 4630 (2006):

All equipment to be deployed for fermentation test should be completely gastight. Glass materials are preferred as they fulfill this criterion so that biogas contact with the environment is avoided. For the first test procedure, $0.5 \mathrm{~L}$ glass bottles with rubber septa were used for preventing leakage of biogas. All five reactors three of which contained the mixture of test sample and inoculum as well as the two blank reactors containing only the inoculum were incubated at a temperature of $38^{\circ} \mathrm{C}$. Manual mixing of reactor contents was done once a day. Measurement of gas volume and composition was done manually using a digital gas analyzer (Geotechnical Instruments Ltd., GA 94)(Figure 1).

For the second and third batch fermentation tests, five $3 \mathrm{~L}$ capacity reactors were used three of these contained the mixture of test sample and inoculum while the other two reactors were filled with the inoculum only to serve as controls. A digital analyzer was connected with the gasstorage jar. Aluminum foil bags were used for collecting the biogas produced prior to measuring its composition (Figure 2).

After setting the whole system it was ensured that the system is leak-free, especially at the hose connections. The filled reactors were incubated in the water bath under mesophilic conditions at $38^{\circ} \mathrm{C}$. A heater fitted in the water bath was used to provide a constant temperature during the fermentation process. The water level of the bath was kept higher than the level of materialscontained in the fermentation tubes. An electric rotor required for mixing reactor contents was provided in the set-up. This was effectively used to regularly mix reactor contents to prevent scum and inactive layer formation.

\section{Biogas production}

Volume of biogas produced was measured daily by water displacement method. The volume in grams of biogas produced was assumed to be equal to the amount of water displacement from a $0.5 \mathrm{~L}$ conical flask provided in the laboratory set-up.

In the case of batch fermentation using the $3 \mathrm{~L}$ reactors, measurement of daily gas volume produced were read directly from the digital analyzer.

Dry gas volume was measured by subtracting the water vapor content in biogas produced from the crude volume of biogas by using the following equation with VDI 4630, 2006 guideline [20]:

$V_{0}^{t r}=V \cdot\left[\left(p-p_{w}\right) \cdot T / p_{0} \cdot T_{0}\right]$

Where, $\boldsymbol{V}_{\boldsymbol{0}}{ }^{\boldsymbol{t r}}$ volume of the dry gas in the normal state, in $\mathrm{ml}_{\mathrm{N}}$

$\boldsymbol{V}$ volume of the dry gas in the normal state, in $\mathrm{ml}$ $\boldsymbol{P}$ pressure of the gas phase at the time of reading, in $\mathrm{hPa}$

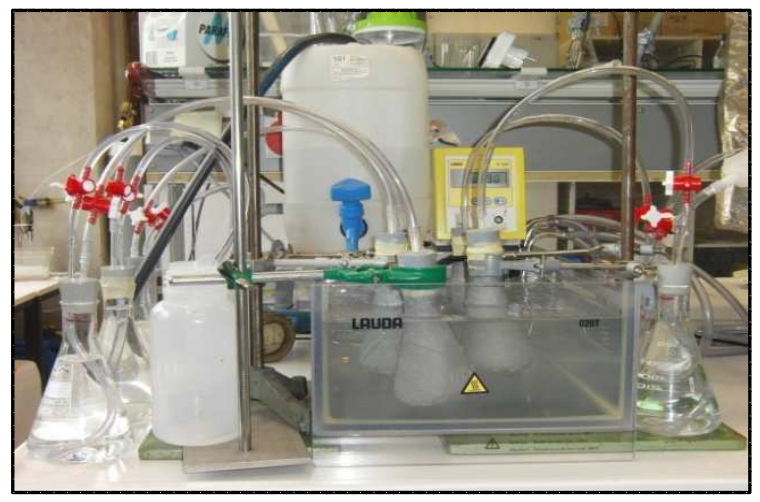

Figure 1: Batch test with $0.5 \mathrm{~L}$ reactor. 
$\boldsymbol{p}_{\boldsymbol{w}}$ vapor pressure of the water as a function of the temperature of the ambient space, in $\mathrm{hPa}$

$\boldsymbol{T}_{\boldsymbol{0}}$ normal temperature; $\boldsymbol{T}_{\boldsymbol{0}}=273 \mathrm{~K}$

$\boldsymbol{P}_{\boldsymbol{0}}$ normal pressure; $\boldsymbol{p}_{\boldsymbol{0}}=1013 \mathrm{hPa}$

$\boldsymbol{T}$ Temperature of the fermentation gas, in $\mathrm{K}$

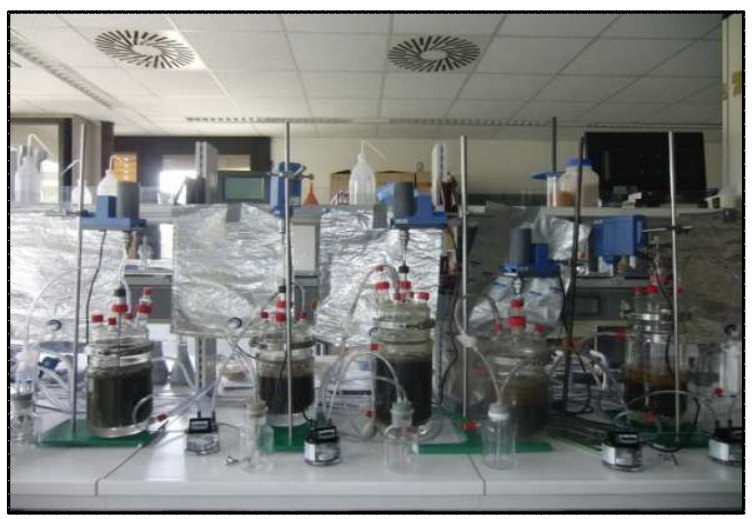

Figure 2: Batch test with $3 \mathrm{~L}$ reactor.

\section{RESULT AND DISCUSSION}

The value of DM, ODM and FOS/TAC of organic waste and inoculum shown in Table 2 were calculated using equation (2), (3) and (4). The $\mathrm{pH}$ value was measured by using a $\mathrm{pH}$ meter.

Table 2: DM, ODM, FOS/TAC and $\mathrm{pH}$ content of organic waste, digested sludge and digested maize silage.

\begin{tabular}{|c|c|c|c|c|c|}
\hline & $\begin{array}{l}\mathrm{DM} \\
(\%)\end{array}$ & $\begin{array}{c}\text { ODM } \\
(\% \mathrm{DM} \\
)\end{array}$ & $\begin{array}{l}\text { FOS/ } \\
\text { TAC }\end{array}$ & $\begin{array}{l}\mathrm{pH} \text { value } \\
\text { (before) }\end{array}$ & $\begin{array}{l}\mathrm{pH} \text { value } \\
\text { (at the end } \\
\text { of } \\
\text { digestion) }\end{array}$ \\
\hline $\begin{array}{l}\text { Bio } \\
\text { waste }\end{array}$ & $\begin{array}{r}20.5 \\
3\end{array}$ & 19.80 & - & - & 7.5 \\
\hline $\begin{array}{l}\text { Sewage } \\
\text { sludge }\end{array}$ & 2.40 & 1.38 & 0.25 & 7.7 & 7.3 \\
\hline $\begin{array}{l}\text { Digested } \\
\text { maize } \\
\text { silage }\end{array}$ & 7.61 & 5.20 & 0.3 & 8.1 & 7.6 \\
\hline
\end{tabular}

\section{Biogas from bio waste and sewage sludge with 0.5 liter} reactor (Test 1)

The anaerobic fermentation of bio waste using sewage sludge as inoculum produced the following cumulative curves for biogas and methane as shown in figure 3 .

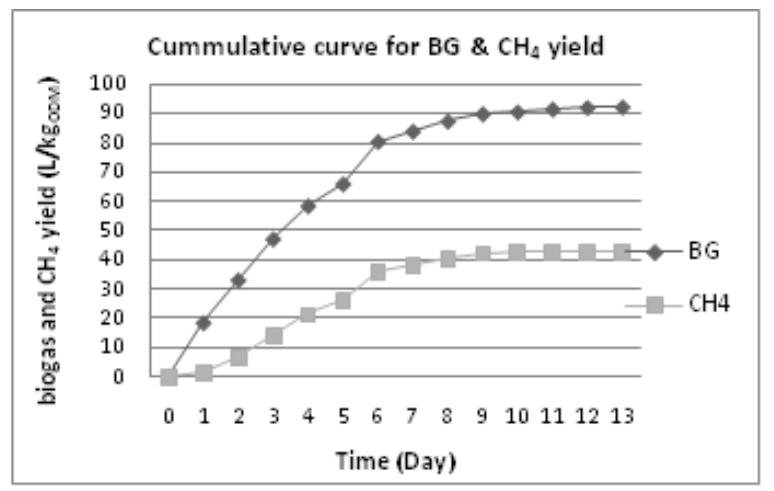

Figure 3: Cumulative biogas and methane production $\left(\mathrm{L} / \mathrm{kg}_{\mathrm{ODM}}\right)$ from bio waste after 13 days (substrate: bio waste; inoculum: sewage sludge).
The average value of biogas was found $92 \pm 29.32 \mathrm{~L} / \mathrm{kg}_{\text {ODM }}$ and for methane was $43 \pm 13.2 \mathrm{~L} / \mathrm{kg}_{\text {ODM }}$ (refers to mean value and standard deviation; table-4).From the graph it can be seen that the quantity of biogas produced from the bio waste. The highest volume of biogas produced after a fermentation period of 13 days was about $92 \mathrm{~L} / \mathrm{kg}_{\text {ODM }}$ with a maximum methane content of about $43 \mathrm{~L} / \mathrm{kg}_{\text {ODM. }}$. Which represents about $46.74 \%$ of the total amount of biogas obtained.

Anaerobic digestion of bio waste with sewage sludge indicated low volume. Bio waste contains a group of carbohydrates with different materials, such as starch, cellulose and hemicellulose and their chemical composition is not uniform for anaerobic metabolism [22]. Tchobanoglous, 2002 [19]; Braber, K., 1995 [23] stated that bio waste is a heterogeneous composition of organic materials that are either, rapidly or slowly biodegradable.According to Lou, X.F. et al. (2012)[24], carbohydrate rich waste haa a low biogas production ranging from $0.33-0.42 \mathrm{~m}^{3} / \mathrm{kg}_{\mathrm{ODM}}$. However, from the test results the highest volume of biogas was recorded to be $0.094 \mathrm{~m}^{3} / \mathrm{kg}_{\text {ODM }}$. Besides the composition of the bio waste used, the low production of biogas can be attributed to the presence of heavy metals and types of microorganism present in the sludge. Production of biogas from sewage sludge is not very promising, because of the presence of heavy metals such as zinc, lead, copper, nickel etc. found in sewage sludge [25] that can negatively influence biogas production. Besides these heavy metals, sewage sludge also contains inorganic compounds, which may contribute to low gas production.

Furthermore, the difference in the rate of methane production may be attributed to the availability of readily degradable substances like carbohydrate. The amount of substrate is also an important factor. The small amount of substrate that was used in Test 1 and Test 3, which were calculated using formula 1 above according to VDI 4630 (2006) [20] makes it impossible to add more substrate to increase the biogas production. Overloading of the reactor with the test substrate can lead to an inhibition of gas production and the breakdown of the fermentation process [26].

In order to produce high amount of biogas there is a need for microorganism to access the substrate. Because the substrates serve as food for the microorganism, the lack of it will reduce biogas production. Due to the lower ODM content of sludge (Table 2), less amount of substrate was used in the batch test with sewage sludge. The rate of biogas production also depends on the carbon content of the inoculum and input substrate, which are not always degraded or converted to biogas through anaerobic digestion [27]. This could also be a reason for low biogas production. Yadvika et al., 2004 [28] stated that high amount of volatile fatty acid and acetic acid produced by microbes and ammonia can also inhibit the biogas production. 


\section{Biogas from bio waste and digested maize silagewith 3 liter reactor (Test 2)}

In the second experiment, 3L capacity reactors were used to determine the biogas yield from the anaerobic digestion of test sample using digested maize silage as source of inoculum. The average value of biogas and methane produced was $568.65 \pm 57.16 \mathrm{~L} / \mathrm{kg}_{\mathrm{ODM}}$ and $217.85 \pm 37.6$ $\mathrm{L} / \mathrm{kg}_{\text {ODM }}$ respectively (table 4 ). The graphics from the second experiment are represents below:

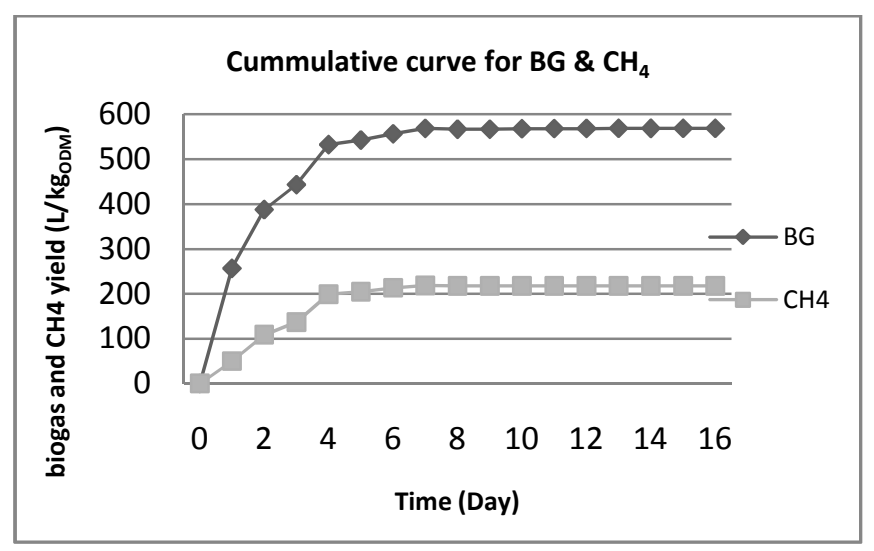

Figure 4: Cumulative biogas and methane production $\left(\mathrm{L} / \mathrm{kg}_{\mathrm{ODM}}\right)$ from bio waste after 16 days (inoculum: digested maize silage).

The above curve shown in figure 4 describes the cumulative biogas and methane produced from the anaerobic fermentation bio waste with digested maize silage as inoculum. The graph represents the quantity of biogas produced, with a maximum cumulative production of about $569 \mathrm{~L} / \mathrm{kg}_{\text {ODM }}$ recorded while the square curve is representative of the cumulative volume of methane produced. A maximum cumulative methane volume of 218 $\mathrm{L} / \mathrm{kg}_{\text {ODM }}$ was observed which represents about $38.31 \%$ of the total dry biogas obtained (table 3 ).

Results from the third test with $3 \mathrm{~L}$ reactor also indicated that anaerobic digestion of bio waste with sewage sludge produced low volume of biogas and methane (Figure 4) similar to that obtained for Test 1 . This result can be linked with the above discussion, which focused onthe composition of bio-waste and sewage sludge. So the reasons of low biogas production from the co-digestion of bio-waste and sludge can be attributed to the following factors: 1) fast degradable substrate 2) presence of heavy metals in sewage sludge 3) types of microorganism in the sludge and their microbial degradation capability and 4) lower ODM content of sludge.

\section{Biogas production from bio waste and sewage sludge with 3 liter reactor (Test 3 )}

The third experiment involved the use of $3 \mathrm{~L}$ capacity reactor for the anaerobic fermentation of bio-wastes using sewage sludge as a source of microorganisms. The average biogas yield and methane was found to be $94 \pm 19.4$ $\mathrm{L} / \mathrm{kg}_{\text {ODM }}$ and $31.32 \pm 10.25 \mathrm{~L} / \mathrm{kg}_{\text {ODM }}$ respectively (table 4 ). The graphics represented by figure5below were obtained for the third test.

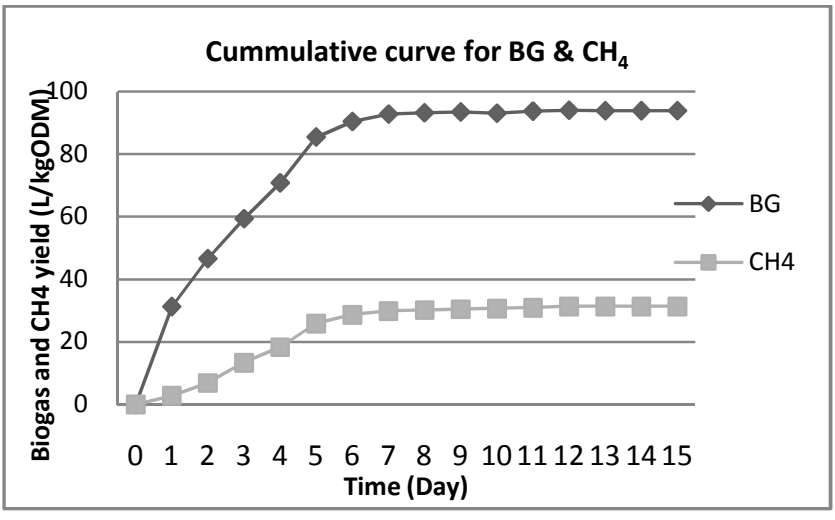

Figure 5: Cumulative biogas and methane yield ( $\mathrm{L} / \mathrm{kg}_{\mathrm{ODM}}$ ) after 15 days (substrate: bio waste; inoculum: sewage sludge).

Figure 5 illustrates the cumulative biogas and methane production from the $\mathrm{AD}$ of bio-waste and sewage sludge inoculum. The curve for biogas shows the quantity of biogas produce having a maximum cumulative production of about $94 \mathrm{~L} / \mathrm{kg}_{\text {ODM }}$ while the maximum cumulative volume of methane produced was observed to be about $31.6 \mathrm{~L} / \mathrm{kg}_{\text {ODM }}$. Methane content represents about $33.62 \%$ of the total dry biogas obtained.

In the second test, the fermentation of bio-waste withdigested maize silage produced higher volumes of biogas and methane compared with the volumes produced from the AD of substrate with sewage sludge as shown in Table 3. Maize silage has high capacity for biogas production and can produce about $40 \%$ methane [22].Yamulki, 2005 [29] reported an increased production of biogas and methane resulting from the high degradation ability of microorganism found in the digested maize silage.

About $0.57 \mathrm{~L} / \mathrm{kg}_{\text {ODM }}$ Biogas and $0.22 \mathrm{~L} / \mathrm{kg}_{\text {ODM }}$ methane was obtained from this experiment, which is much higher than the results obtained with sewage sludge. This can be due to the high content of ODM content of digested maize silage compared to that of sewage sludge as shown in Table 2. Ideally, high volatile solid content produce high yield of biogas and methane due to the presence of more nutrients [30]. R. Omar et al. [30] reported low metal contents are low in digested maize silage.Their presence enhances microbial growth positively. El-Mashad et al. [31] investigated that bio waste and digested maize silage both contained well-balanced nutrients for anaerobic microorganisms. Considering the amount of substrate, we can see that for Test 2 higher amount of substrate was used compared to the other two tests i.e. test with sewage sludge inoculum. The higher amount of substrate increased the amount of organic matter available for biodegradation.

The $\mathrm{pH}$ value was also in the optimal range for Test 2 . According to Doerr et al. [32] Biogas production processes work best at neutral $\mathrm{pH}$ values or slightly above neutral (between 7.0 and 8.5). We found that thepH value of digested maize silage used was slightly alkaline at about 
8.1 whereas sewage sludge had a $\mathrm{pH}$ value of 7.2 as shown in Table 2.

Table 3: Cumulative biogas and methane yield from three different tests.

\begin{tabular}{|c|c|c|c|c|}
\hline Test & $\begin{array}{l}\text { Cumulative } \\
\text { biogas } \\
\text { yield } \\
\text { (L/kgoDM) } \\
\end{array}$ & $\begin{array}{l}\text { Cumulative } \\
\text { methane } \\
\text { yield } \\
\left(\mathrm{L} / \mathrm{kg}_{\text {ODM }}\right) \\
\end{array}$ & $\begin{array}{l}\text { Methane } \\
\text { yield } \\
(\%)\end{array}$ & $\begin{array}{l}\text { Methane } \\
\text { yield } \\
\left(\mathbf{m}^{3} /\right. \\
\left.\mathbf{k g}_{\text {ODM }}\right)\end{array}$ \\
\hline Test 1 & 92 & 43 & 46.74 & 0.043 \\
\hline Test 2 & 569 & 218 & 38.31 & 0.22 \\
\hline Test 3 & 94 & 31.6 & 33.62 & 0.0316 \\
\hline
\end{tabular}

\subsection{Statistical analysis}

Table 4 below shows the comparison of experimental results, which was analyzed using Excel 2007. The table provides information on the cumulative specific biogas and methane yield from the fermentation of bio-waste with sewage sludge and digested maize silage for three different testsperformed. Standard deviation (STDV) was calculated based on the mean value of biogas and methane produced in each experiment. The mean values were calculated by taking the peak value of each reactor. These values were acquired from the error bars, which shows the range of standard deviations.

Table 4: Mean value and standard deviation.

\begin{tabular}{|l|r|r|r|r|}
\hline $\begin{array}{l}\text { Number } \\
\text { of test }\end{array}$ & \multicolumn{1}{|c|}{$\begin{array}{l}\text { Mean } \\
(\mathbf{B G})\end{array}$} & \multicolumn{1}{|c|}{$\begin{array}{l}\text { Mean } \\
\left(\mathbf{C H}_{4}\right)\end{array}$} & $\begin{array}{l}\text { Standard } \\
\text { dev. (BG) }\end{array}$ & $\begin{array}{l}\text { Standard } \\
\text { dev. }\left(\mathbf{C H}_{\mathbf{4}}\right)\end{array}$ \\
\hline Test 1 & 92.132 & 43 & 29.32 & 13.2 \\
\hline Test 2 & 568.65 & 217.85 & 57.17 & 37.6 \\
\hline Test 3 & 94 & 31.32 & 19.4 & 10.25 \\
\hline
\end{tabular}

Biogas producedfrom the digestion of bio-waste with sewage sludge ranged between $63 \mathrm{~L} / \mathrm{kg}_{\mathrm{ODM}}$ and 121.5 $\mathrm{L} / \mathrm{kg}_{\text {ODM }}$ whilemethane production varied between 30 $\mathrm{L} / \mathrm{kg}_{\text {ODM }}$ and $56.2 \mathrm{~L} / \mathrm{kg}_{\text {ODM }}$. Higher volumes of biogas and methane were observed for digested maize silage in comparison to the volumes produced by sewage sludge. Biogas and methane produced from the fermentation of bio-waste with digested maize silage ranged from 511.5 $\mathrm{L} / \mathrm{kg}_{\text {ODM }}$ to $625.62 \mathrm{~L} / \mathrm{kg}_{\text {ODM }}$ for biogas and $180.25 \mathrm{~L} / \mathrm{kg}_{\text {ODM }}$ to $255.45 \mathrm{~L} / \mathrm{kg}_{\mathrm{ODM}}$ for methane.

\subsection{Calculation of total biogas production potential from derived bio waste in Dhaka}

Visvanathan, C. et al. reported that the daily solid waste generation in Dhaka city is 4364 tons (average of dry season and wet season) has been producing from different sources [33].The composition of solid waste in Dhaka city documented from the source of [2] and [4] where organic fraction of waste found about 75\%. DEO, 2004 [34]reported that Solid waste in the study area has a very high organic content that varies from $70-85 \%$.

Based on the above data the daily generation of organic waste by fresh mass (FM) is follows:
$4364 \times 75 \%=3273_{F M}$ tons $/$ day

Total generated organic waste $=3273_{\mathrm{FM}}$ ton/day

The percentage of bio waste varies between $66 \%$ and $68 \%$ was reported by DCC, 2005 [2], the total amount of bio waste generated can be estimated as follows:

\section{8\% (bio-waste) of $3273_{F M}$ tons/day $=2226$ tons/day bio waste}

The ODM result obtained from batch test was 20 (\%DM).Though the dry matter percentage of bio waste is $20 \%$, the amount of solid organic waste becomes = 445 ton $_{\mathrm{ODM}} /$ day.

As mentioned earlier, laboratory scale experiments were carried out in order to assess the biogas production potential of bio waste.

Note:

- Biogas is $50 \mathrm{~m}^{3} /$ ton waste \& electricity generation rate is $2 \mathrm{kWh} / \mathrm{m}^{3}$ of biogas [6].

Daily biogas production potential with the reference of [6] $=445$ ton $_{\mathrm{ODM}} /$ day $\times 50 \mathrm{~m}^{3} /$ ton $_{\mathrm{ODM}}$ $=22,250 \mathrm{~m}^{3} /$ day.

Results from laboratory experimentsusing digested maize silage reveals, maximum biogas and methane of about 569

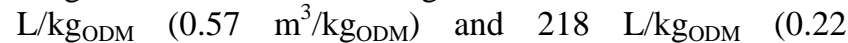
$\mathrm{m}^{3} / \mathrm{kg}_{\text {ODM }}$ ) respectively( see table 4 ). But the use of digested maize silage for biogas production will not be much cost effective due to its low generation in the city of Dhaka.

Subsequently results from the fermentation of bio waste with sewage sludge indicateamaximum volume of biogas and methane of $94 \mathrm{~L} / \mathrm{kg}_{\text {ODM }}\left(0.094 \mathrm{~m}^{3} / \mathrm{kg}_{\text {ODM }}\right)$ and 43 $\mathrm{L} / \mathrm{kg}_{\text {ODM }}\left(0.043 \mathrm{~m}^{3} / \mathrm{kg}_{\text {ODM }}\right)$ respectively (see table 4$)$.

Henceby multiplying amount of waste generated by the maximum biogas yield the volume of biogas produced from the fermentation of total bio waste with sewage sludge the volume of biogas is computed as shown below:

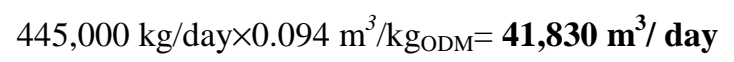

\subsection{Calculation of total electricity generation potential from produced biogas}

Outcomes from the lab experiments were used to calculate the energy generation potential. It is obvious that biogas production from the mixture of bio-waste and digested maize silageis higher than the mixture of bio waste and sewage sludge. However the use of digested maize silage for biogas production in the case study area (Dhaka) is not convenient, due to its low generation in the city. Whileit is possible to source large amounts of digested maize silagefrom the rural areas, thecost of transporting it to Dhaka will be increased the overall cost of the system. On 
the other hand, the availability of large volumes of sewage sludge in Dhaka makes it more accessible for use in biogas production. Thus, it is much more logical to consider the use of sewage sludge despite the lower energy value generated by sewage sludge.

According to lab test result, total electricity generation,

$=41,830 \times 2=83,660 \mathrm{kWh}$

$=83.66 \mathrm{MWh}$

$=83.66 \mathrm{MW}$, which is $3.8 \%$ of the total electricity demand $(83.66 \times 100) / 2200$.

Note: Daily average demand in Dhaka city (approximate) = 2200 MW [35]

\section{CONCLUSION}

This study was conducted to assess the biogas yield potential from municipal organic solid wastes when treated separately with two different inoculums sewage sludge and digested maize silage. Discussions form the preceding result highlights the possibilities of deploying bio waste in biogas production for energy recovery as a means of promoting green energy from waste. Though the results from the laboratory fermentation of bio waste with sewage sludge indicated lower volumes of methane and biogas, the use of sewage sludge as a source of inoculum for biogas generation cannot be overruled owing to its availability in comparison to the quantity of digested maize silage available in Dhaka city. In general for an effective operation of a biogas plant the supply of input substrate and inoculum is paramount. While it is relatively possible to manage solid waste in Dhaka, the management of sewage sludge requires advanced planning so as to facilitate the operation of biogas production. The results indicated that higher volume of $94 \mathrm{~L} / \mathrm{kg}_{\text {ODM }}$ of biogas was obtained from municipal organic waste and sewage sludge mixture. Statistical analysis reveals that both sources of inoculum had significant effect on biogas and methane gas production. The value of $94 \mathrm{~L} / \mathrm{kg}_{\text {ODM }}$ was considered for calculating the biogas and electricity generation potential. The overall assessed value of biogas was $41,830 \mathrm{~m}^{3} /$ day and electricity from derived biogas was $83.66 \mathrm{MW}$, which is $3.8 \%$ of the daily demand in Dhaka city.

\section{REFERENCES}

[1] BBS, 2012.Bangladesh Bureau of Statistics, Peoples Republic of Bangladesh.

[2] Dhaka City Corporation (DCC) \& Japan International Cooperation Agency (JICA) (2005): Clean Dhaka Master Plan; The Study on the Solid Waste Management in Dhaka City.

[3] Islam R. et al.(2008): Renewable energy resources and technologies practice in Bangladesh. Renewable and Sustainable Energy Reviews, 12(2), pp.299-343.
[4] UN HABITAT(2010).Solid waste management in the world cities.United Nations Human Settlement Program.

[5] Japan International Cooperation Agency (JICA) (2012): Clean Dhaka Newsletter; Strengthening of Solid Waste Management in Dhaka city (Extension).

[6] Asian Development Bank (ADB) 2011: Toward sustainable Municipal Organic Waste Management in South Asia.

[7] Wellinger, A. (2005): Biogas production and Utilization, IEA Bio energy: T37:2005:01

[8] Alam, H. (2012, Aug, 18) Power from garbage: Govt-run plant to generate $50 \mathrm{MW}$ electricity using garbage of Dhaka city, The Daily star, Front Page, available at: http://www.thedailystar.net/newDesign/newsdetails.php?nid=246632.

[9] Singhal, Y. et al. (2012): Evaluation of Biogas Production from Solid Waste using Pretreatment Method in Anaerobic Condition. Int. J. Emerg. Sci., 2(3), 405-414 Dayalbagh Educational Institute, Dayalbagh, Agra, India-282110.

[10] Krutwagen, B. et al. (2008): Analysis of Existing Studies that Use a Life Cycle Approach to Assess the Environmental Performance of Different Options for the Management of the Organic Fraction of Municipal Solid Waste. JRC scientific and technical report. Available at: http://lct.jrc.ec.europa.eu/pdfdirectory/Inventory-of-existing-studies-applying-lifecycle-thinking-to-biowaste-management.pdf

[11] Alam et al (2001) 4th International Conference on Mechanical Engineering, December 26-28, 2001, Dhaka, Bangladesh/pp. I 125-130

[12]Alastair J. Ward, Phil J. Hobbs, Peter J. Holliman, David L. Jones (2008): Optimization of the anaerobic digestion of agricultural resources. Bioresource Technology 99 (2008) 7928-7940.

[13] Xiguang Chen, Rowena T. Romano, Ruihong Zhang. Anaerobic digestion of food wastes for biogas production. Int J Agric\&BiolEng, 2010; 3(4): 61-72.

[14] Wakadikar K, Sil A, Kumar S, Kumar R, Mudhoo A (2012) Influence of Sewage Sludge and Leachate on Biochemical Methane Potential of Waste Biomass. J BioremedBiodeg S8:002. doi:10.4172/2155-6199.S8002 .

[15] T. Bond, M. R. Templeton, 2011: History and future of domestic biogas plants in the developing world, 15 (2011) 347-354.

[16] A.J. Ward et al., 2008: Optimization of the anaerobic 
digestion of agricultural resources, Bioresource Technology 99, 7928-7940.

[17] P. Sosnowski et al., 2003: Anaerobic co-digestion of sewage sludge and organic fraction of municipal solid wastes. Advances in Environmental Research 7 (2003) 609-616.

[18] Davidsson, A., C. Gruvberger, T.H. Christensen, T.L. Hansen and J.L.C. Jansen, 2007. Methane yield in source-sorted organic fraction of municipal solid waste.Waste Management, 27: 406-414. DOI: 10.1016/j.wasman.2006.02.013.

[19] Tchobanoglous, G. (2002): Solid Waste Management, University of California at Davis, California- USA.

[20] VereinDeutscherIngenieure (VDI) 4630 (2006): VDIGesellschaftEnergietechnik, Fermentation of organic materials characterization of the substrate, sampling, collection of material data, fermentation test.

[21] Lossie, U. and Pütz, P. (2008): Targeted control of biogas plants with the help of FOS/TAC, LABORATORY ANALYSIS TITRATION, FOS/TAC. Web: www.hach-lange.com

[22] Th. Amon et al. (2006): Optimierung der Methanerzeugung aus Energiepflanzen mit dem Methanenergiewertsystem. Berichte aus Energie- und Umweltforschung.

[23] Braber, K. (1995): Anaerobic digestion of municipal solid waste: A modern waste disposal option on the verge of breakthrough, Biomass and bioenergy, Vol. 9, Nos 1-5, pp. 365-376.

[24] Lou, X.F. et al. (2012): Influence of Food Waste Composition and Volumetric Water Dilution on Methane Generation Kinetics. International Journal of Environmental Protection, Vol. 2 Iss. 9, PP. 22-29.

[25] Rulkens, W. (2008): Sewage Sludge as a Biomass Resource for the Production of Energy: Overview and Assessment of the Various Options. Energy \& Fuels 2008, 22, 9-15.

[26] Gaduš, J. and Kročko, V. (2006): Evaluation of Cofermentation under agricultural biogas plant condition. MOTROL, 2006, 8A, 125-132.

[27] Budiyono et al., 2009, Increasing Biogas Production Rate from Cattle Manure Using Rumen Fluid as Inoculums. International Journal of Basic \& Applied Sciences IJBAS-IJENS Vol: 10 No: 01. Available at: http://www.ijens.org/101501-8282\%20IJBAS-

IJENS.pdf

[28] Yadvika.,Santosh., Sreekrishnan, T.R., Kohli, S., Rana, V. (2004). Enhancement of biogas production from solid substrates using different technique: Bioresource Technology, 95:1.

[29] Yamulki, S. (2005). Effect of straw addition on nitrous oxide and methane emissions from stored farmyard manures. Agriculture, ecosystems and environment, 112:140-145.

[30] R. Omar et al., 2008. Anaerobic Treatment of Cattle Manure for Biogas Production. Available on: http://www.nt.ntnu.no/users/skoge/prost/proceedings/a iche-2008/data/papers/P130128.pdf

[31] El-Mashad and. Zhang (2010): Biogas production from co-digestion of dairy manure and food waste. Bioresource Technology 101 (2010) 4021-4028

[32] Doerr, B. and Lehmkuhl, N. (2008): Methane digesters. Eco technical note, USA. Web: http://www.echonet.org

[33] Visvanathan, C. and Glawe, U. (2006): Domestic Solid Waste Management in South Asian Countries - A Comparative Analysis. Asian Institute of Technology, Thailand.

Available at:http://www.faculty.ait.ac.th/visu/Prof\%20Visu's\%20 CV/Conferance/25/3R-MSWM.\%20Visu.pdf

[34] Department of Environment (DOE), Waste Concern and ITN-BUET (2004): SAARC workshop on solid waste management, country paper-Dhaka, Bangladesh.

[35] Power Grid Company of Bangladesh Ltd. (PGCB) 2012: http://www.pgcb.org.bd/

\section{BIOGRAPHY}

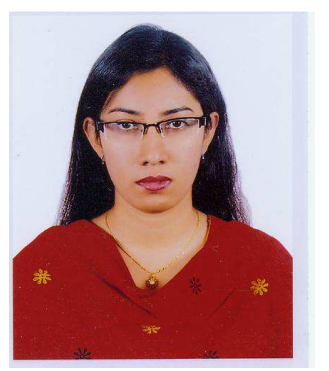

Nusrat Jahan Imu

Research Assistant

Daffodil International University

Dhaka, Bangladesh

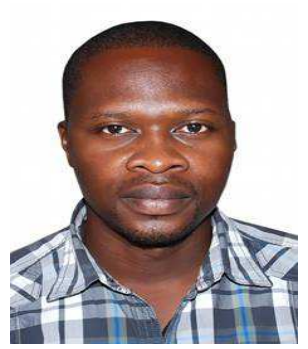

Dido Mann Samuel

Assistant Lecturer

Federal University, Ndufu-Alike

Ikwo (FUNAI).

Nigeria. 